慶應義塾大学学術情報リポジトリ

Keio Associated Repository of Academic resouces

\begin{tabular}{|c|l|}
\hline Title & Plasma concentration of acetylcholine in young women \\
\hline Sub Title & \\
\hline Author & $\begin{array}{l}\text { 川島, 紘一郎(Kawashima, Koichiro) } \\
\text { 大畑, 尚代(Ohata, Hisayo) } \\
\text { 藤本, 和子(Fujimoto, Kazuko) } \\
\text { 鈴木, 岳之(Suzuki, Takeshi) }\end{array}$ \\
\hline Publisher & 共立薬科大学 \\
\hline Publication year & 1988 \\
\hline Jtitle & $\begin{array}{l}\text { 共立薬科大学研究年報 (The annual report of the Kyoritsu College of } \\
\text { Pharmacy). No.33 (1988. ),p.154- 154 }\end{array}$ \\
\hline JaLC DOI & \\
\hline Abstract & \\
\hline Notes & 抄録 \\
\hline Genre & Technical Report \\
\hline URL & https://koara.lib.keio.ac.jp/xoonips/modules/xoonips/detail.php?koara_id=AN00062898-0000003 \\
& $3-0154$ \\
\hline
\end{tabular}

慶應義塾大学学術情報リポジトリ(KOARA)に掲載されているコンテンツの著作権は、それぞれの著作者、学会または出版社/発行者に帰属し、その権利は著作権法によって 保護されています。引用にあたっては、著作権法を遵守してご利用ください。

The copyrights of content available on the KeiO Associated Repository of Academic resources (KOARA) belong to the respective authors, academic societies, or publishers/issuers, and these rights are protected by the Japanese Copyright Act. When quoting the content, please follow the Japanese copyright act. 
№. 33 (1988)

\title{
Plasma concentration of acetylcholine in young women
}

\author{
Koichiro Kawashima, Hisayo Oohata, Kazuko Fujimoto, \\ and Takeshi SuzUKI \\ 川島紘一郎, 大畑尚代, 藤本和子, 鈴木岳之
}

A sensitive and specific radioimmunoassay was applied to the determination of acetylcholine $(\mathrm{ACh})$ in plasma. The concentration of $\mathrm{ACh}$ in plasma sampled from 32 young women was $456.1 \pm 53.1$ (mean \pm S.E.M.) $\mathrm{pg} / \mathrm{ml}$. No significant correlations were observed between plasma concentration of $\mathrm{ACh}$ and acetylcholinesterase (AChE) activity, or gonadal hormones. These data demonstrate that an amount of $\mathrm{ACh}$ measurable by radioimmunoassay is present in plasma and plasma $\mathrm{ACh}$ is not regulated by $\mathrm{AChE}$ activitiy and the menstrual cycle in young women. The origin and physiological as well as pathophysiological significance of $\mathrm{ACh}$ in plasma remain to be clarified.

* 本報告は Neuroscience Letters, 80, 339-342（1987）に発表. 